\title{
YOUTH EMPLOYMENT AND ENTREPRENEURIAL SKILLS DEVELOPMENT IN THE AJUMAKO- ENYAN-ESSIAM DISTRICT OF GHANA
}

\author{
Francis Enu-Kwesi \\ Institute for Development Studies \\ University of Cape Coast \\ Cape Coast, Ghana \\ Email: fenu-kwesi@ucc.edu.gh or enukwesi@yahoo.com, \\ and \\ Akanganngang Joseph Asitik \\ Dept. of Economics and Entrepreneurship Development \\ Faculty of Integrated Development Studies \\ University for Development Studies \\ Wa, Ghana \\ Email: asitikj@yahoo.com \\ doi:10.4314/gjds.v9i1.6
}

\begin{abstract}
In order for the people of a country or district to achieve their individual aspirations and collectively contribute toward development they need to be entrepreneurial. This requires some form of training and education in order to develop the relevant skills, knowledge and attitudes requisite for meaningful employment. Using descriptive statistics, this paper examines the links between unemployment situation and youth enterprise in the Ajumako-Enyan-Essiam District (AEED) in the Central Region, one of the four poorest administrative regions of Ghana. It found that majority of the youth had at most secondary education, and were unemployed, underemployed or self-employed in informal micro-enterprises. Though entrepreneurial opportunities existed in the District, the youth were adequately involved in the requisite entrepreneurship training programmes that would enable them to take advantage of the existing opportunities in order to reduce youth unemployment or under-employment. It concludes that though the youth have entrepreneurial potentials, their low educational attainment has been a challenge to training. It has therefore been suggested that the District Assembly encourages training and educational institutions that incorporate entrepreneurship in their curriculum in order to provide trainees with the needed knowledge, skills and competencies for employment.
\end{abstract}

KEY WORDS: Entrepreneurial skills, education and training, youth employment, microenterprise development, community development

\section{INTRODUCTION}

Goulet (1971) and Todaro (1997) identify the core values of development to include life sustenance, self-esteem and freedom from servitude. These together are concerned with the provision of basic needs such as housing, clothing, food and education as well as self-respect and independence. They indicate that no country can be considered as fully developed, if it remains in economic and political subjugation to another powerful nation. Consequently, development must be such that people are more able to determine their own destiny. According to Sen (1999), the well-being of humans should take centre stage and that development should be evaluated in terms of the expansion of people's capabilities to lead the kind of lives that they 
value, and have reason to value. Sen continues that no one person is free if he or she cannot choose or is imprisoned by living on the margins of subsistence with no education and skill. Hence, development should ensure the total well-being of the individual. In order to achieve this, human resource development should be the core of any developmental process. Harbinson (1973) argues that human resource, the active and superior agent, constitutes the ultimate basis of the wealth of nations as it coordinates both capital and physical resources, by accumulating capital, exploiting available natural resources, and building the needed socio-economic and political organs for national development. Acheampong (2006) adds to Harbinson's argument by focusing on the human capital theory which espouses that training and development and skill acquisition will enhance productivity, growth and development. This is the state that developing countries seek in order to improve the lives of their citizenry.

However, in order for the people of a country, area or district to achieve their individual aspirations, and collectively contribute toward development they need to be entrepreneurial (Naude, 2008), since entrepreneurship is one of the factors that propel development. This requires some form of training and education in order to develop the relevant skills, knowledge and attitude needed to undertake economic activities. The emphasis on entrepreneurship is informed by the fact that governments, especially those in developing countries, including Ghana, are constrained in employment creation, due mostly to resource scarcity and donor conditionality restrictions on public sector employment.

The constraints in employment creation tend to affect the youth the most and the World Bank estimates that by the year 2015 there will be three billion people in the world who are under the age of 25 (Youth Business International [YBI], 2009). Although this generation will be the most educated ever, they will face a sustained rise in unemployment, and current estimates are that 40 per cent of the world's unemployed are young people. According to Mkandawire and Soludo (2003) and Aryeetey (2006), the inadequacy of formal sector jobs has driven the youth to seek refuge in the informal economy, a sector that De Soto (1989) described as characterized by low wages, lack of social security, lack of health benefits, and whose conditions of work are outside the sphere of public scrutiny.

The consequence of structural adjustment requirements such as the restriction of formal sector employment is poverty arising from a deficit of decent work opportunities. In addition to the structural changes, Coenjaerts, Ernst, Fortuny, Rei and Pilgrim (2009) argue that poverty, underemployment and unemployment are due to the large number of young people who enter the labour market each year in poor economies and the low quality of education and training, often de-linked from the labour market. This has economic costs in terms of gross domestic product gap and can also result in social conflicts and juvenile delinquency.

Dualist theorists, including Swaminathan (1991), argue that the operators in the informal sector have hopes of better prospects and movement away from temporary marginal economic activities. They recommend modernization or formalization of the sector through the provision of income and economic assets, education and skills, safe housing and sanitary conditions, access to health care and other social services, networks, and personal resourcefulness (Miller, Mastuera, Chao \& Sadowski, 2004). Thus, in order to invigorate employment creation and reduce poverty, they agree with structural theorists' proposition for entrepreneurial training which should focus on the youth. This is linked to Benjamin-Schonberger's (2010) argument that the youth have the greatest potential to bridge gaps between businesses and the poor because they are more connected and idealistic, and have action-oriented mind sets geared for change.

Kruger (2004) opines that entrepreneurship begins with action, the creation of new organizations including the antecedents to their creation; inter alia, scanning the environment for opportunity, the identification of the opportunity to be pursued, and the evaluation of the 
feasibility of the new venture. The antecedents can be found in decentralization as a development paradigm, and the establishment of entrepreneurial support organizations in several parts of the developing world. The ability to scan the environment and recognize opportunities can be aided by education and training. Economists have come to recognize the input-completing and gap-filling capacities of entrepreneurial activity in innovation and growth, and the significant contribution of innovation and growth to employment creation, prosperity and economic welfare (Acs \& Armington, 2006; Audretsch, 2007; Schramm, 2006) in all countries, including Ghana.

The various ministries that deal with youth, employment and social welfare, including the Ministry of Local Government and Rural Development (2006) report that reliable statistics on the exact nature and levels of youth unemployment in Ghana are not readily available, and whatever is available varies from agency to agency. However, it is acknowledged that a fairly high proportion of those in the 15-35 year group remain largely unemployed or underemployed. In order to address the gaps in the labour market, three groups of young people who require support were identified for training. The skills and entrepreneurial development programme priorities were to increase the relevance and coverage of vocational and technical training; develop and expand the traditional apprenticeship system; and promote entrepreneurship among the youth (NDPC, 2003).

In its efforts to better the lives of her citizens, Ghana has formulated different development plans at different times, including the poverty reduction strategies (GPRS I \& II) and the shared growth and development agenda 2010-2013 (NDPC, 2003; 2009). The various plans take cognizance of the gaps in skills and entrepreneurial development notwithstanding the numerous youth focused training programmes, including the Skills Training and Employment Placement (STEP), the National Youth Fund (NYF), the Regional Technology Transfer Unit (RTTU) and the Integrated Community Centres for Employable Skills (ICCES). In this regard, the Medium-Term Development Programme (MTDP) framework of the Ghana Shared Growth and Development Agenda (GSGDA) (2010-2013), includes the establishment of entrepreneurial training institutions in order to enhance skills' development and youth employment (NDPC, 2009).

The implementation of the entrepreneurial development programmes was expected to occur within the framework of decentralization. The implication is that district assemblies and supporting institutions in the various districts will collaborate and focus on skills development in order to address the high rates of youth unemployment in Ghana, especially in deprived rural districts, including the Ajumako-Enyan-Essiam District (AEED). The AEED, with a population of 91,965 and a projected youthful population of 26,688 was rated as one of the poorest districts in one of the four poorest regions in the country and with a high rate of youth unemployment (Ghana Statistical Service, 2005).

Though the District is endowed with resources such as fertile land, water bodies for fishing, timber for carpentry and carving, and palm nut among others that can be developed to create employment opportunities for both the unemployed and the under-employed youth, poverty is widespread among the youth. About 85 per cent of the youth are engaged in rain fed agriculture with low productivity, yielding low output and incomes (AEED, 2004). This is as a result of the youth lacking the required knowledge and skills to adopt modernized agricultural practices for improved productivity and incomes.

In order to diversify youth economic activities and reduce unemployment and juvenile delinquency, the District Assembly decided to provide the youth with entrepreneurial skills by allocating $\$ 6.6$ million in its Plan of Action for the year 2000 to train a number of youth to acquire employable skills after conducting a needs assessment (AEED, 2004a). 
The focus of the Assembly was to provide an enabling environment for the private sector to add value to primary products to increase their monetary value. However, from 1996 up to 2005, the Assembly assisted in training only ten out of the estimated number of 200 people selected (AEED, 1996; 2004b). Similarly, the attempt of the District Youth Council (DYC) in 2004 to train 114 youth leaders to acquire entrepreneurial skills failed (DYC, 2004). The failure of the entrepreneurial training programmes planned by the District Assembly and other bodies raises concerns because they impinge upon efforts at addressing youth unemployment for poverty reduction.

\section{METHODOLOGY}

The study was conducted in the Ajumako-Enyan-Essiam District (AEED) in the Central Region of Ghana, with a population of 91,965 (Ghana Statistical Service, 2002) and a growth rate of 1.3 per cent. The main economic activities in the District are farming, agro-processing of oil palm fruits to oil, gari and wood carving (AEED, 2004a). Using a descriptive design, the study focused on the youth of the AEED and examined the employment situation and entrepreneurial skills development efforts in the District without comparing or contrasting with any other different environment.

The target population was young people aged between 15 to 35 years in the District, and key informants from related entrepreneurial skills development institutions. The annual population growth rate of 1.3 (AEED, 2004a) was used to project the population of the youth, yielding a youth population of 26,688 in the District. A mixture of simple random and convenience sampling procedures were used to select and obtain responses through interviews, from 105 youth from membership of business owners in youth groups, youth in training institutions, and unemployed youth, based on the homogeneous nature of the study population.

A household list was obtained from the District Assembly, and Microsoft Excel's random number generation analysis tool was used to select the 105 households with the intent of interviewing any youth respondent. However, wherever a selected household was not applicable a convenient one was substituted. The youth were homogeneous by age group, operate in the same environmental conditions and face the same challenges in the AEED, so the substitution did not undermine the essence of the study. This conforms to Sarantakos' (2005) view that if the population is homogeneous with respect to the study object, a small sample may suffice.

Six key informants from the training institutions and District Assembly were also purposively selected and interviewed as part of the study. Tools from the Statistical Product and Service Solutions (SPSS) software version 11 and Microsoft excel were employed to generate descriptive statistics, showing frequencies and percentages.

\section{SOME THEORETICAL AND CONCEPTUAL ISSUES}

Even though insufficient funds (economic factor) may impede entrepreneurial training, Personality Traits Theory, a Psychological Theory, suggests that regardless of variations in economic development, entrepreneurs with high motivation always maximize economic achievement. The Theory pays attention to traits, motives and incentives of an individual and concludes that entrepreneurs have a strong need for achievement (McClelland, 1961; McClelland \& Winter, 1971). Deducing from the locus of control theories, the entrepreneur believes in his or her capabilities to undertake activities and complete them through his or her own actions (Amit, Glosten \& Muller, 1993; Low \& MacMillan, 1988). Entrepreneurs are people with high goals to achieve, control their destiny, prefer to be independent and responsible for their actions, feeling that they can create and be apt to innovating challenges and trust their ability to manage risk (Scheré, 1982). Although the Personality Traits Theory seems to work, it 
is important that it should be linked with the society as a whole, since the individual is a social being, living in a particular environmental context with its unique social and cultural processes. Consequently, the decisions that are taken in the broader context of national development are likely to have an effect on individuals' entrepreneurial decision-making, depending upon their personality traits but also socio-cultural and economic milieu.

Petrin (1994) discusses the importance of seeing the link between individual entrepreneurial aspirations and societal goals because all genuine entrepreneurship is social, with the entrepreneur aiming to provide a service or good that can capture a share of the market or even create a new market. This argument can be made even more forcefully within the context of entrepreneurship and rural development where the creation of rural enterprises can create employment, reduce poverty and reduce the need for social support. Hence, the motivations of the people who start new businesses should not be unusually highly individualistic or focused solely on self-fulfilment (Benjamin-Schonberger, 2010). The motivation for entrepreneurs in starting new businesses should transcend the improvement of their standard of living, the presence of an individual personal plan and the attainment of higher social status and respect, and rather drive at helping the general society.

On its part, ethnic identification of sociological enterprise tries to explain entrepreneurship as a process where the individual's sociological background is one of the decisive "push" factors in becoming an entrepreneur (Reynolds, 1991). This is because individuals draw their values from the ethnic group they are associated with and are mostly influenced by such groups e.g. family, co-workers or broader groups such as occupational groups among whom they draw inspirations and experience.

Whether ascribed or achieved, entrepreneurial capabilities are dependent upon the societal context. Capabilities for economic initiatives are a reflection of society and its culture, as such economic activities in general and entrepreneurial activities in particular, are part of sociocultural structures (Johannisson, 1984). However, ability to use sophisticated modern technologies require high level of numeracy skills (Lall, 1999), in addition to entrepreneurial skills such as technical skills and business management skills (Hisrich and Peters (2002). These skills may be acquired through formal education, vocational training, in-firm training, specialised employee training outside the firm and learning on the job.

In this regard, small business education provides practical help that enables people to change from employed to self-employment, but designing good programmes and teaching strategies present challenges to young entrepreneurs. Gibb (1985) presents three key problems that have emerged from the evaluation of such programmes. These are the differing perceptions of teachers and potential small business owners on what start-up programmes should ideally contain indications of deficiencies in many current start-up programmes and the length of such programmes. Those taking these classes find them too general (Sym \& Lewis, 1987) and Curran and Stanworth (1989) agree that vital aspects of many entrepreneurial education and training programmes such as content, teaching strategy and evaluation of their effectiveness remain largely under-researched.

Additionally, Role Identity Theory shows that transitions in work roles cause changes in the set of activities that constitute the content of the work (Poutsma, 1994). According to Poutsma, this creates self-awareness and leads to assessments of one's own abilities, interests and beliefs in relation to entrepreneurial ability. However, the youth in such a situation need to acquire some experience by learning from others or their own failures. This is so because entrepreneurial activity is based on experiential learning that comes out of mistakes, which provide guiding experience and can only be carried out in an action framework where young entrepreneurs can identify and explore existing opportunities or even creating them. Young entrepreneurs can achieve their individual or collective visions through concrete actions. In this regard, economics 
of overview and supply-oriented personal networks show the importance of the interface between formal and informal enterprise, between businesses and communities, and between the individual entrepreneurs and the community (Poutsma, 1994).

Entrepreneurship is a highly creative economic process. It differentiates entrepreneurs from the rest of the population. It requires the youth to be creative, innovative and knowledgeable to cope with the changing needs of the market. Garavan and O'Cinneide (1994) suggest that it should be part of secondary school syllabuses and undergraduate programmes in order to increase participant awareness of industry. They recognize, however, that most entrepreneurs are specialists and not general managers and that the real entrepreneur organizes others and taps into the knowledge and expertise required on all aspects (Garavan \& O'Cinneide, 1994; Vesper, 1982). Gibb (1987) suggests that the educational system emphasises a set of values and abilities which is inimical to entrepreneurial skills development, and thus hinders the prospects of creating jobs or entrepreneurs.

Entrepreneurship has the potential to create youth employment and integrate the youth into the economic mainstream while addressing some of the socio-psychological and delinquency problems that arise from joblessness (Chigunta, 2002; Curtain, 2001). Youth enterprises provide marginalized youth with a sense of 'meaning' and 'belonging', shape their identity and encourage others to treat and accept them as equal members of society and also promotes innovation and resilience as they are encouraged to find new solutions, ideas and methods of doing things through experience-based learning (OECD, 2001; White \& Kenyon, 2000 cited in Chigunta, 2002). This requires the youth to be resourceful, have initiative, imagination, enthusiasm, dash, ambition, energy, vitality, boldness and courage (Schnurr \& Newing, 1997:2 cited in Chigunta, 2002) in order to fight global youth unemployment. It is estimated that youth unemployment constitutes 47 percent (88 Million) of global unemployment, making the youth vulnerable to social exclusion (ILO, 2005a).

Globally, self-employment is an important source of employment, livelihoods and economic dynamism (OECD, 2001). Effective youth entrepreneurship education prepares young people to be responsible, enterprising individuals who become entrepreneurial thinkers and contribute to economic development and sustainable communities (Chigunta, 2002). One important thing is that young entrepreneurs gain a sense of accomplishment that comes from knowing that they did something useful with little or no supervision (Johanson \& Vahlne, 2003) and is the greatest reason to raise a young entrepreneur.

\section{EMPIRICAL RESULTS AND DISCUSSIONS}

The first part of the analyses focus on the education and training, youth employment situation, and infrastructure in the District, while subsequent attention is devoted to entrepreneurial skills development. Under entrepreneurial skills development, the discussions cover technical, business management and personal skills. Other issues covered are entrepreneurial competency formation, and institutions and key informants' assessment of the entrepreneurial aspirations of the youth. The findings are based on responses from 105 youth and six key informants. Out of the six key informants three were from the District Assembly, and the other three were from the Centre for Rural Enterprise Development, Business Advisory Centre of the National Board for Small Scale Industries, and the District Youth Council.

\section{Entrepreneurial Potentials and Preparedness}

According to Chigunta (2002), effective youth entrepreneurship education prepares young people to be responsible, enterprising individuals who become entrepreneurs and contribute to sustainable economic development. This presents the kind of transformation that entrepreneurship can bring about in an individual's life and provides a basis to examine how 
the educational system promotes entrepreneurship as well as the benefits associated with it. In this regard, 69.9 per cent of youth respondents stated that the current school system provides graduates with basic knowledge and skills to start their own business. However, 30.1 per cent stated that it is only skill-based subjects such as technical and vocational skills that can provide basis for business start-up. According to them, the current educational system is theoretical with less emphasis on vocational and technical programmes. As a result, there is a gap especially between secondary education output and the requirements for entrepreneurship.

Skills and availability of start-up capital provide an enabling environment for businesses to do well and in this case, an enabling environment comprises basic infrastructure such as electricity, telephone service, good road network and good drinking water. Table 1 indicates that there exist basic business support facilities for promoting successful production, trade and networking in order to facilitate business development in the District.

Table 1: Perception about basic infrastructure in the AEED

\begin{tabular}{lll}
\hline Facilities & Frequency & Per cent \\
\hline Telephone service & 89 & 26.80 \\
Good road network & 53 & 16.00 \\
Electricity services & 98 & 29.50 \\
Good drinking water & 92 & 27.70 \\
\hline Total & $332^{*}$ & 100.00 \\
\hline
\end{tabular}

*Note: Total responses (332) are more than the total sample of 105 due to multiple responses.

Source: Field source, 2010

\section{Youth employment situation}

A total of 105 youth participated in the study. This was made up of 55 per cent males and 45 per cent females. All of them were below 35 years as shown in Table 2, with the majority (63.8\%) between 15 and 19 years old. These age groups, together with the low level of formal education, usually find themselves unemployed or in the informal, micro-enterprise economy (Palmer, 2007).With the exception of three of them, the rest had some formal education mostly in the form of basic (44.76\%), secondary (33.33\%) and technical/vocational (11.45\%). A few had either training college, polytechnic or university education.

Table 2: Background characteristic of respondents

\begin{tabular}{llll|lll}
\hline Age & Sex & & & Educational attainment & \\
& Male & Female & Total & Level attained & Frequency & Percentage \\
\hline $15-19$ & 35 & 32 & 67 & None & 3 & 2.85 \\
$20-24$ & 20 & 14 & 34 & Basic & 47 & 44.76 \\
$25-29$ & 2 & 1 & 3 & Secondary & 35 & 33.33 \\
$30-34$ & 1 & 0 & 1 & Technical/Vocational & 12 & 11.45 \\
$35-39$ & 0 & 0 & 0 & Training college & 2 & 1.91 \\
$40-44$ & 0 & 0 & 0 & Polytechnic & 3 & 2.85 \\
$45-49$ & 0 & 0 & 0 & University & 3 & 2.85 \\
\hline Total & 58 & 47 & 105 & Total & 105 & 100 \\
\hline
\end{tabular}

Source: Field survey, 2010

Specifically, with regard to the youth employment situation, 49.5 per cent out of the 105 sampled youth who responded were working while 50.5 per cent were not working. Among those working, 25 per cent owned their businesses, and only 5.77 per cent of this category was females. Only 11 out of those working considered their jobs as full-time. The rest, especially the females were employees in the informal micro-enterprise economy. These are the kinds of 
workers that work outside the sphere of public scrutiny and whose conditions of work are characterized by low wages, lack of social security, and lack of health benefits (De Soto, 1989).

Thirty nine of the unemployed youth preferred self-employment to being employed by some other people. In doing that, they will create jobs for themselves and for people they may employ, thus reducing unemployment and helping to address some of the socio-psychological and delinquent problems by bringing back the alienated and marginalised youth into the economic mainstream (Curtain, 2001; White \& Kenyon, 2000 cited in Chigunta, 2002). This however, requires some entrepreneurial knowledge and skills which can impact positively on lives since available data suggest that there are no countries with high levels of entrepreneurship and low levels of economic growth (Reynolds et al., 2002).

Four out of six institutional or key informants indicated that there was high youth unemployment, but the remaining two claimed that youth underemployment was the problem in the District. Both viewpoints reflect the general characterization by the employment and youth related ministries, including the Ministry of Local Government and Rural Development (2006) that the 15-35 age groups suffer from unemployment and under-employment. Three key informants attributed the youth unemployment situation to limited employment opportunities in the District but two attributed it to the lack of drive such as creativity and innovativeness on the part of the youth, while one claimed that the youth were selective and prefer white-collar jobs which were non-existent. As a follow-up, all the key informants admitted that although there were skills training programmes available, none of those could be described as entrepreneurship training.

\section{Entrepreneurial Skill and Values}

For any form of activity to be carried out successfully, a particular skill will be required. However, skills need to be combined with values to ensure successful entrepreneurship. This section therefore combines discussions of both skills and values as a way of examining entrepreneurial skills development in the District. The youth who participated in the study admitted that they needed special skills that would enable them enter the world of business. However, apart from the usual apprenticeship training in welding, masonry and other artisanal activities, they were oblivious of the changes in technology and the likely impact on jobs and business prospects. Though, 57.7 per cent of the youth consider technical skills as most important for the take-off of entrepreneurial activities, combining the three categories of skills is very essential in undertaking business opportunities since multiple skilling is required as production jobs have changed across board, shifting from less skilled to more skilled (ILO, 2005a).

Technical skills involve skills such as writing, listening, presenting and organising as well as being a team player and possessing technical know-how (Hisrich \& Peters, 2002). In assessing the skills of the youth in oral communications, 96 per cent stated that people easily understand them when they speak. Out of this number, 86 per cent attributed this to varied reasons including good communication skills and trustworthiness. On the subject of listening, which helps in the making of informed decisions, 90.7 per cent said that they listen to people, even if they have sound knowledge about what is being discussed, because that provides them with more information (47.7\%), and also shows respect (25.2\%). The presence of these skills offers opportunities for the youth to be consulted during employment policy making and entrepreneurship training design (ILO, 2005b).

Technical skills alone do not ensure success. They must be combined with business management skills which include human relations, decision making, and negotiation among others as part of the entrepreneurial journey (Hisrich \& Peters, 2002). With respect to human relations, 91.3 per cent of the 105 youth stated that they enjoy relating with people, mainly 
through social interactions, which include friendship, meetings, association activities and discussions. Since business is a social interaction between people, it could be a good foundation for building good customer relations. One other reason cited was that they want to assist people and be assisted by others. This indicates a commitment to teamwork which is needed in the business world, especially when it comes to the formation of business partnership where expertise is to be shared for the mutual benefits of the partners. They also stand the chance of improving upon their activities since they share ideas.

Keeping information and tasks in order is essential in any human activity because it facilitates the achievement of set goals. In this regard, 98.1 per cent out of the 105 youth indicated that their interest is in ensuring that information and tasks are kept orderly. This enables them to make quick references, stay focused, build business confidence, avoid getting into difficulties, improve performance, and maintain customers. These reasons, related to life skills, are according to Hisrich and Peters (2002), very essential in business since information management is a very important entrepreneurial competency.

In embarking on an activity or assignment, the first thing is to decide whether to undertake that activity, how to do it and what results to expect. Though this is the initial stage of the activity, it is the crucial stage. Taking a decision is one step, but the most important thing is business management skills or the ability to carry out activities that will lead to realizing the results of such a decision especially when challenges are encountered. Mariotte and Towle (2001) pointed to the importance of negotiations during transactions in order to derive mutually beneficial conclusions, in personal or business arrangements. In this regard, 96.2 per cent of the youth noted that they have negotiation skills and like bargaining any time they tried to make purchases because it helps to manage scarce money well and leads to increased profits through a reduction in costs.

The difference between an entrepreneur and a manager is the interpersonal skills of the entrepreneur. It includes skills such as discipline, risk taking, innovativeness, persistence, visionary leadership and being change-oriented (Hisrich \& Peters, 2002; McClelland, 1961). Regarding innovativeness, 80.8 per cent of the youth wanted to do things differently from what has been established; an indication of entrepreneurial qualities (Benjamin-Schonberger, 2010). The reasons provided are that they want to create markets for their products $(21.3 \%)$, create new inventions $(17.5 \%)$ or create things of excellence $(16 \%)$. This is a reflection of the youth's natural disposition for innovation and change which can be capitalised upon as long as it is clear that successfully launching a new enterprise is an innovative process and a great opportunity for society to exploit (Benjamin-Schonberger, 2010; OECD, 2001).

However, 19.2 per cent of the youth said they were not interested in doing things differently from well-established methods. Some said a "well-established way of doing things are quite better than methods that are not tested." Some also said they wanted to avoid bad practices which would attract criticism. This shows that these categories of youth are not innovative and enterprising and lack the potential for becoming entrepreneurs (McClelland, 1961).

On the subject of risk taking, 47.1 per cent of the 105 youth were ready to take risks as a sign of determination and to make profits. However, 52.9 per cent would not take risks because they are unsure of the outcomes, and thus would not like to waste resources. The views of these two groups show that taking risk means different things to different people, but entrepreneurs are widely believed to be willing to assume moderate risks and there is a relationship between risk and entrepreneurial activities (McClelland, 1961). In terms of trying new ideas, which is an indication of risk taking, 86.5 per cent of the youth said they are eager to try new ideas and 96.9 per cent of these offered that experimentation leads to new ideas and products, enables response to change and promotes business growth. 
Generally, there are indications that the youth are potential innovators and can bring about business growth since innovativeness brings about successful entrepreneurs (Chigunta, 2002; Johanson \& Vahlne, 2003; Johannisson, 1984; Low \& Macmillan, 1988). However, 13.5 per cent of the youth do not accept change with the reason that well-known methods are best because they have been tested overtime and their end products are known and accepted.

The last issue examined was the institutional or key informants' assessment of the entrepreneurial skills of the youth and the results are presented in Table 3. The issue was examined based on ratings by the key informants. The scale for the final ratings is a three point scale with Good $=3$, Fair $=2$ and Poor $=1$. The assessment considered all the elements of the three components of entrepreneurship, namely, technical, management and personal skills.

Observing the weighted totals, which are the scale values multiplied by total responses for each category, the youth are doing well in all the three aspects since 18 is the highest weighted total. This means that the youth are potential entrepreneurs and can make it if they are able to undergo entrepreneurial training. The ratings are similar to the responses that the youth gave about themselves in relation to the three types of skills, an indication that the youth who form part of the district human resource have a higher potential productivity value and must be encouraged.

Table 3: Institutions ratings of youth entrepreneurial skills

\begin{tabular}{|c|c|c|c|c|}
\hline Skills & Ratings & Good & Fair & Poor \\
\hline \multirow{7}{*}{ 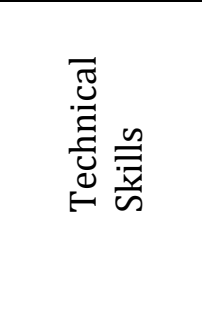 } & Innovativeness & 2 & 2 & 2 \\
\hline & Risk Taking & 2 & 0 & 4 \\
\hline & Change Orientation & 0 & 2 & 4 \\
\hline & Seeking Opportunity & 0 & 3 & 3 \\
\hline & Visionary Leadership & 2 & 2 & 2 \\
\hline & Total respondents & 6 & 9 & 15 \\
\hline & Weighted totals & 18 & 18 & 15 \\
\hline \multirow{7}{*}{ 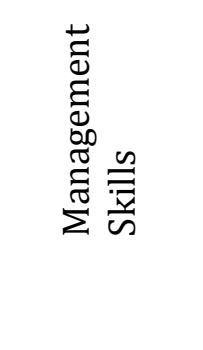 } & Ability to Plan and Set Goals & 2 & 1 & 3 \\
\hline & Ability to Analyse and Evaluate & 0 & 2 & 4 \\
\hline & Decision Making & 0 & 4 & 2 \\
\hline & Knowledge in Marketing & 2 & 1 & 3 \\
\hline & Knowledge in Finance & 2 & 0 & 4 \\
\hline & Total respondents & 6 & 8 & 16 \\
\hline & Weighted Totals & 18 & 16 & 16 \\
\hline \multirow{6}{*}{ 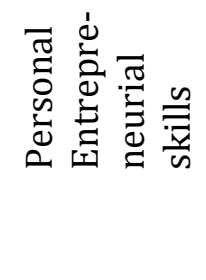 } & Effective Interaction & 2 & 2 & 2 \\
\hline & Ability to Negotiate & 2 & 1 & 3 \\
\hline & Ability to Organise & 0 & 2 & 4 \\
\hline & Network Building & 2 & 0 & 4 \\
\hline & Total respondents & 6 & 5 & 13 \\
\hline & Weighted totals & 18 & 10 & 13 \\
\hline
\end{tabular}

Source: Field survey, 2010

\section{CONCLUSIONS AND POLICY IMPLICATIONS}

The youth of the District are lowly educated, and mostly unemployed, self-employed or underemployed in the informal micro-enterprise economy. They have acquired some technical skills from skills training programmes and their basic to secondary/technical level education. Their 
views on innovativeness, perseverance and human relations show an entrepreneurial disposition. This can combine well with the presence of entrepreneurial opportunities to create a favourable environment for entrepreneurship training.

Though the District Assembly has earlier made attempts to provide skills training to the youth in AEED and failed, due to unavailability of funds, the Assembly should persist and find means of raising the needed funds to promote youth entrepreneurship training programmes to complement the skills that are offered by the existing training programmes and the regular school system. These training programmes should include risk-taking as part of their contents, the potentials of the district, and also cover general information about changes that are occurring in the global economy and its impact on the Ghanaian and hence the district's economy. The design of such programmes should however, take into account the low level of education of the youth in order to make them attractive and ensure delivery effective.

\section{REFERENCES}

Acheampong, I. K. (2006). Human resource development: Labour market concepts and operations. Cape Coast: Catholic Mission Press.

Acs, Z. J. and Armington, C. (2006). Entrepreneurship, geography and American economic growth. Cambridge: Cambridge University Press.

Ajumako-Enyan-Essiam District Assembly (1996). Development Plan, Ajumako: AEED.

Ajumako-Enyan-Essiam District Assembly (2004a). District Profile, Ajumako: AEED.

Ajumako-Enyan-Esiam District Assembly (2004b). Poverty situation in AEED.

Newsletter (1) 1-15. Ajumako: AEED.

Amit, R.; Glosten, L. and Muller, E. (1993). 2Challenges to theory development in entrepreneurship research." Journal of Management Studies, (30): 815 - 833.

Aryeetey, E. (2006). The informal economy: Economic growth and poverty in SubSaharan Africa. A paper presented at the African Economic Research Consortium Project Workshop on Understanding the links between Growth and Poverty Reduction in Africa (Unpublished).

Audretsch, D. B. (2007). The entrepreneurial society. Oxford: Oxford University Press.

Benjamin-Schonberger, I. (2010). Romania and the need for a new entrepreneurial culture. Washington, DC: Center for International Private Enterprise.

Chigunta, F. (2002). Youth entrepreneurship: Meeting the key challenges._England: Wolfson College, Oxford University.

Coenjaerts, C.; Ernst, C.; Fortuny, M.; Rei, D. and Pilgrim, M. (2009). Youth employment. In OECD (2009). Promoting pro-poor growth: Employment. Paris, FR: OECD.

Curran, J. and Stanworth, J. (1989). "Education and training for enterprise: Some problems of classification, evaluation, policy and research." International Small Business Journal, 7: 2-14.

Curtain, R. (2001). "Youth employment and entrepreneurship: A policy perspective." Development Bulletin, 55 (August 2001): 7-11. 
De Soto, H. (1989). The other path: The economic answer to terrorism. London: IB Taurus/ Harper Collins.

District Youth Council. (2004). Ajumako-Enyan-Essiam District Assembly Annual Report: Ajumako: AEED.

Garavan, T. N. and O' Cinneide, B. (1994). "Entrepreneurship education and training programmes: A review and evaluation”. Journal of European Industrial Training, (18): $11-21$.

Ghana Statistical Service (2002). 2000 Population and Housing Census: Special report on 20 large localities. Accra: Ghana Statistical Service.

Ghana Statistical Service (2005). Ghana living standards survey: Report of the fourth round. Accra: Ghana Statistical Service.

Gibb, J. (1985). Factors affecting the survival and growth of the smaller company. Gower: Aldershot.

Gibb, A. A. (1987). "Enterprise Culture: Its meaning and implications for education and training." ournal of European Industrial Training, (11): 2-18.

Goulet, D. (1971). The cruel choice: A new concept in the theory of development. New York: Athenaeum.

Harbinson, F. (1973). Human Resource Management. New York: Routledge.

Hisrich, R. D., \& Peters, M.P. (2002). Entrepreneurship. International edition. Singapore: McGraw-Hill.

ILO. (2005a). World employment. Geneva: International Labour Organisation.

ILO. (2005b). Youth: Pathways to decent work. Report VI: Promoting youth employment, Tackling the challenge. International Labour Conference. 93 ${ }^{\text {rd }}$ Session. Geneva: ILO.

Johannisson, B. (1984). "A cultural perspective on small business: Local business climate." International Small Business Journal, (2): 31-41.

Johanson, J., and Vahlne, J. E. (2003). Business relationship learning and commitment in the Internationalization process. International Marketing Review, 7: 11-24.

Kruger, M. E. (2004). Entrepreneurship theory and creativity. Pretoria: University of Pretoria.

Lall, S. (1999). The technological response to import liberalization in Sub- Saharan Africa. London: Macmillan

Low, M. B. and MacMillan, I. C. (1988). "Entrepreneurship: Past research and future challenges.” \ournal of Management. (14): 139 - 161.

Mariotti, S. and Towle, T. (2001). Entrepreneurship: How to start and operate a small business. A guide for the young entrepreneur. New York. The National Foundation for Teaching Entrepreneurship (NFTE). 
McClelland, D. (1961). The achieving society. Princeton, NJ: D. Van Nostrand.

McClelland, D. C. and Winter, D. G. (1971). Motivating economic achievement. New York: The Free Press.

National Development Planning Commission (2003). Ghana Poverty Reduction Strategy I. Accra: NDPC.

Miller, M. L.; Mastuera, M.; Chao, M. and Sadowski, K. (2004). Pathways out of poverty: Early lessons of the family independence initiative. Oakland: Family Independence Initiative.

Ministry of Local Government and Rural Development. (2006). The youth unemployment problem: Ghana Districts- A repository of all districts in Ghana. Accra: MLGRD.

Mkandawire, T. and Soludo, C. C. (eds.) (2003). African voices on structural adjustment: A comparison to our continent, our future. Johannesburg: Africa World Press Inc.

Naude, W. (2008). Entrepreneurship in economic development. Helsinki, Finland: United Nations University, UNU-WIDER (World Institute for Development Economics Research). Research Paper No. 2008/20.

OECD (2001). Fostering entrepreneurship. Paris: Organisation for Economic Cooperation and Development.

Palmer, R. (2007). Skills development, the enabling environment and informal microenterprise in Ghana. Unpublished Ph. D thesis. Centre of African Studies, School of Social and Political Sciences, The University of Edinburgh. UK (Unpublished)

Poutsma, E. (1994). Coordination or participation: Labour policy in small scale processinnovating companies. Research workshop on trends in entrepreneurship research, Gent. (17th March)

Reynolds, P. D. (1991). "Sociology and entrepreneurship: Concepts and contributions." Entrepreneurship: Theory and Practice, 16: 47 - 67.

Reynolds, P. D.; Bygrave, W. D.; Erkko, A.; Larry W. C. and Michael, H. (2002). Global Entrepreneurship Monitor 2002: Executive Report. Wellesley, MA/London: Babson College/London Business School.

Sarantakos, S. (2005). Social research (3 $3^{\text {rd }}$ ed.). New York, NY: Palgrave Macmillan.

Scheré, J. (1982). "Tolerance for ambiguity as a discriminating variable between entrepreneurs and managers." Academy of Management Proceedings, 22: 404-408.

Schramm, C. J. (2006). The entrepreneurial imperative. New York: Harper Collins.

Sen, A. (1999). Development as freedom. Oxford: Oxford University Press.

Swaminathan, M. (1991). Understanding the informal sector: A survey. MIT Centre for International Studies, Cambridge, Massachusetts: MIT Press.

Sym, L.A. \& Lewis, J.W. (1987). Educational needs of small business start-ups: An 
Investigation of short course revision. Paper presented to the 10th National Small Business Policy and Research Conference, Cranfield, UK. November, 1987.

(Unpublished).

Todaro, M. P. (1997). Economic development. (6th Ed.). New York: Addison-Wesley Publishing Company.

Vesper, K. H. (1982). Research on education for entrepreneurship. In C. A. Kent; D. Sexton and K. H. Vesper (Eds.). Encyclopaedia of Entrepreneurship (321-349). Englewood Cliffs, NJ: Prentice Hall.

Youth Business International. (2009). Youth entrepreneurship: Recommendations for action. London: The Prince's Youth Business International, The Prince's Charities. 